Nowoczesne Systemy Zarządzania

Zeszyt 15 (2020), nr 2 (kwiecień-czerwiec)

ISSN 1896-9380, s. 41-55

DOI: $10.37055 /$ nsz/132934

Modern Management Systems

Volume 15 (2020), No. 2 (April-June)

ISSN 1896-9380, pp. 41-55

DOI: $10.37055 / \mathrm{nsz} / 132934$
Instytut Organizacji i Zarządzania Wydział Bezpieczeństwa, Logistyki i Zarządzania

Wojskowa Akademia Techniczna

w Warszawie

Institute of Organization and Management Faculty of Security, Logistics and Management Military University of Technology

\title{
Communication and Knowledge Management in Innovative Enterprises - Literature Review Perspective
}

\section{Komunikacja i zarządzanie wiedzą w innowacyjnych przedsiębiorstwach - przegląd literatury}

\author{
Elena-Madalina Vatamanescu \\ National University of Political Studies and Public Administration \\ in Bucharest Faculty of Management \\ madalina.vatamanescu@facultateademanagement.ro, ORCID: 0000-0002-9397-0385
}

\section{Wioletta Wereda}

Military University of Technology, Faculty of Security, Logistics and Management wioletta.wereda@wat.edu.pl, ORCID: 0000-0002-6948-0239

\section{Jacek Woźniak}

Military University of Technology, Faculty of Security, Logistics and Management jacekj.wozniak@wat.edu.pl, ORCID: 0000-0001-7592-0109

\begin{abstract}
The main goal of this study is to show how the communication with the main stakeholders in innovative enterprises influences the knowledge management and sharing in the innovative processes. The research method are the critical analysis of the literature, as well as the synthesis. Based on the carried out analyses indicated that knowledge management and knowledge sharing are key to innovative processes and should exploit the potential of ICTs. In addition, the communication with stakeholders - both using traditional and modern means - should be implemented in innovative processes. Traditional forms of communication with stakeholders should not be depreciated. The form of communication determines processes of knowledge management, so it should arise from the possibilities, needs and limitations of the different classes of stakeholders, as well as an enterprise itself.

Keywords: stakeholders, knowledge management, communication, relationship management, innovative enterprise
\end{abstract}


Abstrakt. Głównym celem opracowania jest wskazanie, w jaki sposób komunikowanie się z głównymi interesariuszami w innowacyjnych przedsiębiorstwach wpływa na zarządzanie wiedzą i jej wymianę w procesach innowacyjnych. Metody badawcze to krytyczna analiza literatury, a także synteza. $\mathrm{Na}$ podstawie przeprowadzonych analiz wskazano, że zarządzanie wiedzą i dzielenie się nią ma kluczowe znaczenie dla procesów innowacyjnych i powinno wykorzystywać potencjał ICT. Ponadto komunikowanie się z interesariuszami - z wykorzystaniem zarówno tradycyjnych, jak i nowoczesnych środków komunikowania się - powinno być wdrażane w procesach innowacyjnych. Tradycyjne formy komunikowania się z interesariuszami nie powinny być deprecjonowane. Forma komunikacji determinuje procesy zarządzania wiedzą, więc powinna wynikać z możliwości, potrzeb i ograniczeń różnych grup zainteresowanych stron, a także samego przedsiębiorstwa.

Słowa kluczowe: interesariusze, zarządzanie wiedzą, komunikowanie się, zarządzanie relacjami, innowacyjne przedsiębiorstwo

\section{Introduction}

Over the last decades, researchers and science theorists have documented the increased role of stakeholders in strategic management, mainly concentrated on gaining knowledge, values, engagement and connected with risk and a flow of intellectual capital (Freeman, 2004; Friedman, Miles, 2009; Bourne 2009; Sachs, Rühli, 2011). The very important fact is that stakeholders are not a monolith, nor do they all require the same level or type of communication strategies (Maxwell, Carboni, 2014). That is why, it should be noted that they demand as well traditional and emergent (e.g. social media) communication channels. Communication with stakeholders should also be integrated into innovative processes, underpinning the business of modern enterprises, aimed at creating values for different stakeholder classes (not just customers). In addition, in order to manage innovations, there should be taken into account knowledge management and knowledge sharing processes-which cannot take place without properly implemented processes of communication with stakeholders (especially in the digital era).

The research problem is: What is the role of knowledge management and knowledge sharing in innovative enterprises, as well as how it should be incorporated in innovative processes? The article is also an attempt to give a synthetic answer to the question: How should contemporary enterprises communicate with their stakeholders in order to ensure that the value generated for different stakeholder groups (internal and external) is at an expected and high level?

\section{Communication process with stakeholders in current enterprises}

Due to the different authors and cross-discipline researchers the debate about definitions of stakeholders has been shown in the literature. Thus, "stake" is defined in many ways (Freeman, 2004; Friedman, Miles, 2009; Bourne 2009; Sachs, Rühli, 2011), for example as an interest in something (a person or groups is affected be 
a decision related to the activity or its outcomes), right to something (to be treated in a certain way or to have a particular right protected), ownership to the organization (a circumstance when a person or groups has a legal title to an asset or a property), knowledge required (specialist knowledge or organisational knowledge), impact or influence on something (impacted by the activity and an influence on the activity or its outcomes), contribution to some activity (supply of resources and/or advocacy for objects or activity success).

In the literature has been found the information that the earliest definition of stakeholders has been introduced by Stanford Research Institute in 1963 as those groups without whose support the organization would cease to exist. Then many other scholars developed definitions on different criteria as objectives, strategy, cooperation, building relations, trust, etc. (Wereda et al., 2016). According to the classic definition of a "stakeholder" by R.E. Freeman is any group or individual who can affect or is affected by the achievements of the organization's objectives (Freeman, 1984). Due to Friedman and Miles stakeholder definitions are classified on the basis of their strategic and normative dimensions and can be divided on varied criteria. There can be distinguished definitions with a very high strategic implication that limit stakeholders to those that are critical or affect the very survival of existence of the organization.

At the normative dimensions there are definitions with a very high strategic implication that involve legal or institutional conditions that may force organizations to deal with stakeholders, such as through contracts, explicit or implicit. In the middle there are definitions that define stakeholders in terms of their power, influence or ability to affect the organization. In the table below there is a division of stakeholders based on the middle dimension-criterion of influence and involvement (Table 1).

According to seven principles of stakeholder management, all of them point out the meaning of communication process in managing relations with stakeholders. Especially first principle arises from a need to recognize the existence of diverse and multiple stakeholders interests and concentrates on forcing managers of enterprises to acknowledge and actively monitor the concerns of all legitimate stakeholders. Therefore, two-way dialogue, the second principle, is a prerequisite for good stakeholder management, mostly by listening and an open communication with each group of interests about their respective concerns and contributions (Friedman, Miles, 2009). The modern enterprise contacts its internal and external stakeholders both through direct and indirect channels of communication. The main division into contemporary communication tools (traditional and modern) is detailed in Table 2 . 
Table 1. Characteristics of stakeholders in the organization (criterion of influence and involvement)

\begin{tabular}{|c|c|}
\hline \multicolumn{2}{|c|}{ Stakeholders of the basic degree of influence and direct involvement } \\
\hline $\begin{array}{l}\text { 1. Internal and close } \\
\text { to them } \\
\text { (directly related } \\
\text { to the tasks of the } \\
\text { company) }\end{array}$ & $\begin{array}{l}\text { Owners, shareholders, management, employees and their families, former } \\
\text { employees, pensioners, applicants for employment, apprentices, members } \\
\text { of informal groups in the enterprise, proxies, advisers, supervisory boards, } \\
\text { works councils/employee organizations, members in member organizations, } \\
\text { their democratic bodies/authorities. }\end{array}$ \\
\hline $\begin{array}{l}\text { 2. External } \\
\text { (related to the tasks } \\
\text { of the company in } \\
\text { a more or less direct } \\
\text { way) }\end{array}$ & $\begin{array}{l}\text { Shareholders, stockholders, members of co-ownership bodies, persons influential } \\
\text { towards co-owners, representation of members in association bodies, competitors/ } \\
\text { non-industry competitors, e.g. operating in the same labour market, capital, know- } \\
\text {-how, opinions, values, ideas; ad hoc competitors, commercial agencies and/or } \\
\text { other intermediaries in sales and supplies, development funds; strategic partners } \\
\text { (business); customers/buyers/users/consumers; cooperatives, their members and } \\
\text { unions; banks and other financial institutions, dealers, brokers, lobbying organi- } \\
\text { zations; consulting companies; consumer organizations, employee organizations, } \\
\text { trade unions, employers' associations, other industry and professional economic } \\
\text { communities and arrangements, business associations, advertising and marketing } \\
\text { agencies, public relations, members of social and professional organizations. }\end{array}$ \\
\hline \multicolumn{2}{|c|}{ Stakeholders of the second degree of influence and indirect involvement } \\
\hline $\begin{array}{l}\text { So-called general } \\
\text { environment -au- } \\
\text { thorities at various } \\
\text { levels and regula- } \\
\text { tory institutions in } \\
\text { the economy and } \\
\text { social life }\end{array}$ & $\begin{array}{l}\text { Governmental and state organs, their agencies and members, including } \\
\text { members of local self-government bodies, deputies, senators and other poli- } \\
\text { ticians operating within the state organs, at various levels decision-making/ } \\
\text { decision-making bodies in the field of social, political, economic and cultural } \\
\text { life decisions, i.e. regulatory organizations/institutions operating on the labour } \\
\text { market, financial market, in social policy-appropriate ministries, government } \\
\text { agencies of state institutions, financial institutions, trust offices; judicial au- } \\
\text { thorities; advocates of consumer/governmental matters with interest groups, } \\
\text { state employment agencies, tax and customs services. }\end{array}$ \\
\hline \multicolumn{2}{|r|}{ Stakeholders of further degrees of influence and further involvement } \\
\hline $\begin{array}{l}\text { 1. Opinion-forming } \\
\text { circles }\end{array}$ & $\begin{array}{l}\text { Mass media, journalists, journalists' organizations, editorial offices, correspon- } \\
\text { dents (including foreign), editorial offices of company (company) newspapers, } \\
\text { press departments of institutions and surrounding companies, universities } \\
\text { and their authorities, students and their representations, university promotion } \\
\text { departments, graduates' associations, councils employers and graduates, leaders } \\
\text { of views and opinions originating from various areas of public life-influential } \\
\text { representatives of cultural, educational, political, religious institutions, creative } \\
\text { associations, a wide audience of influential media, guests visiting enterprises. }\end{array}$ \\
\hline $\begin{array}{l}\text { 2. Citizens' initia- } \\
\text { tives and similar }\end{array}$ & $\begin{array}{l}\text { Non-governmental organizations that protect the natural environment, fre- } \\
\text { edoms and civil rights, culture; consumer associations; other grassroots } \\
\text { institutions of public life; societies acting to solve social and health problems, } \\
\text { environmental protection organizations etc. }\end{array}$ \\
\hline $\begin{array}{l}\text { 3. The environment } \\
\text { of the enterprise } \\
\text { and international } \\
\text { institutions }\end{array}$ & $\begin{array}{l}\text { Diplomatic missions, diplomats, consular offices of embassies; representatives of } \\
\text { foreign organizations and authorities; affiliations of international organizations. }\end{array}$ \\
\hline
\end{tabular}

Source: Own elaboration based on: (Wereda et al., 2016; Szwajca, 2016; Wójcik, 2011) 
Table 2. Basic forms of communication in relation of the enterprise and its stakeholders

\begin{tabular}{|c|c|}
\hline $\begin{array}{c}\text { Kind of } \\
\text { communication }\end{array}$ & Communication tools used in the process of connecting \\
\hline Traditional & $\begin{array}{r}\text { Paper documentation, face to face communication, telephone communica- } \\
\text { tion; PR; direct sales, advertisement; fairs and exhibitions; }\end{array}$ \\
\hline Modern & $\begin{array}{c}\text { Internet technologies; e-mail accounts; teleconferences; Intranet and } \\
\text { Extranet technologies. Enterprise's/corporates portals (personalized user } \\
\text { accounts); external messengers, e.g. Gadu-Gadu, GTalk, Hangout, Skype, } \\
\text { etc.; external memory cases, e.g. for storing and sharing documents; social } \\
\text { networks, e.g. Facebook, Google+, LinkedIn, Twitter, etc. }\end{array}$ \\
\hline
\end{tabular}

Source: (Woźniak, Wereda, 2018; Maxwell, Carboni, 2014)

The communication of each company with stakeholders is crucial for acquiring and sharing knowledge, and in the long-term building relationships based on trust. What's more, the amount and scope of knowledge about a trusted site affects the level of risk in mutual relations. Sources of information about a stakeholder may be different, more or less credible (Sztompka, 2007). Therefore, first of all an important fact is the open and honest communication between partners, and secondly the type of media in order to avoid communication disturbances. In reference to the statements of many authors, the company exists thanks to information and communication, because the nature of the company, like any organization, is expressed in the processes of communication and the process of communicating with stakeholders (Szwajca, 2016; Schreiber, 2001; Schultz et al., 2002; Friedman, Miles, 2009; Bourne 2009; Sachs, Rühli, 2011). What is more, in the process of adapting the organization to changes in the market, one of the most important aspects of modern enterprises is taking into account the involvement and benefits of stakeholders and building loyalty relationships with the environment, which may result in the development of various types of values and forms of two-way communication (Wereda, 2018).

Due to different needs and expectations of individuals or groups, we can distinguish different goals and content of information as well forms of communication between the company and stakeholders. Examples of content and forms of communication with key stakeholders in the enterprise are presented in Table 3. 
Table 3. Content and goals of enterprise's communication with key stakeholders

\begin{tabular}{|c|c|c|c|c|}
\hline \multirow{2}{*}{$\begin{array}{c}\text { Key } \\
\text { stakeholders }\end{array}$} & \multirow{2}{*}{$\begin{array}{l}\text { Contents of } \\
\text { messages }\end{array}$} & \multirow{2}{*}{$\begin{array}{l}\text { The purpose of } \\
\text { communication }\end{array}$} & \multicolumn{2}{|c|}{ Examples of forms of communication } \\
\hline & & & Traditional & Modern \\
\hline Employers & $\begin{array}{l}\text { The goals and } \\
\text { mission of the } \\
\text { company, plans } \\
\text { and tasks, re- } \\
\text { sults of opera- } \\
\text { tions, incentive } \\
\text { system }\end{array}$ & $\begin{array}{l}\text { Opinion: a good } \\
\text { and fair em- } \\
\text { ployer, creating } \\
\text { a positive em- } \\
\text { ployer brand }\end{array}$ & $\begin{array}{l}\text { Paper documentation; } \\
\text { face to face communi- } \\
\text { cation; telephone com- } \\
\text { munication; e-mail ac- } \\
\text { counts, public relations; } \\
\text { Intranet and Extranet }\end{array}$ & $\begin{array}{l}\text { Social networks; } \\
\text { external memory cases, } \\
\text { e.g. for storing and } \\
\text { sharing documents }\end{array}$ \\
\hline Clients & $\begin{array}{l}\text { The scope and } \\
\text { quality of the } \\
\text { product offer, } \\
\text { rules and stan- } \\
\text { dards of cus- } \\
\text { tomer service, } \\
\text { loyalty program }\end{array}$ & $\begin{array}{l}\text { Opinion: reli- } \\
\text { able and cred- } \\
\text { ible partner and } \\
\quad \text { supplier }\end{array}$ & $\begin{array}{l}\text { Advertisement; personal } \\
\text { sale; public relations }\end{array}$ & $\begin{array}{l}\text { Social networks; Enter- } \\
\text { prise's/corporate's por- } \\
\text { tals (personalized user } \\
\text { accounts); external } \\
\text { messengers }\end{array}$ \\
\hline $\begin{array}{l}\text { Business } \\
\text { partners } \\
\text { (suppliers, } \\
\text { subcontrac- } \\
\text { tors, etc.) }\end{array}$ & $\begin{array}{l}\text { Terms and pos- } \\
\text { sibilities of co- } \\
\text { operation }\end{array}$ & $\begin{array}{c}\text { Opinion: reliable } \\
\text { and trustworthy } \\
\text { contractor }\end{array}$ & $\begin{array}{l}\text { Fairs, exhibitions, nego- } \\
\text { tiations face to face and } \\
\text { paper documentation; } \\
\text { telephone communica- } \\
\text { tion; e-mail accounts }\end{array}$ & $\begin{array}{l}\text { External memory cases, } \\
\text { e.g. for storing and shar- } \\
\text { ing documents; Social } \\
\text { networks, Enterprise's/ } \\
\text { corporate's portals } \\
\text { (personalized user ac- } \\
\text { counts); external mes- } \\
\text { sengers; social networks }\end{array}$ \\
\hline Investors & $\begin{array}{l}\text { Financial re- } \\
\text { sults and in- } \\
\text { vestment and } \\
\text { development } \\
\text { plans }\end{array}$ & $\begin{array}{c}\text { Opinion: A con- } \\
\text { scious and re- } \\
\text { sponsible busi- } \\
\text { ness entity }\end{array}$ & $\begin{array}{l}\text { Annual report in paper } \\
\text { form; Reporting meet- } \\
\text { ings, paper and elec- } \\
\text { tronic brochures }\end{array}$ & $\begin{array}{c}\text { Enterprise's/corporate's } \\
\text { portals (personalized } \\
\text { user accounts); exter- } \\
\text { nal messengers; social } \\
\text { networks }\end{array}$ \\
\hline Media & $\begin{array}{l}\text { Explanation of } \\
\text { important deci- } \\
\text { sions, changes } \\
\text { and crises }\end{array}$ & $\begin{array}{l}\text { Opinion: an } \\
\text { open and reli- } \\
\text { able partner; } \\
\text { good employer } \\
\text { and producer }\end{array}$ & $\begin{array}{l}\text { Public relations; public- } \\
\text { ity; fairs, exhibitions }\end{array}$ & $\begin{array}{l}\text { Enterprise's/corporate's } \\
\text { portals (personalized } \\
\text { user accounts); exter- } \\
\text { nal messengers; social } \\
\text { networks }\end{array}$ \\
\hline $\begin{array}{l}\text { Public ad- } \\
\text { ministration }\end{array}$ & $\begin{array}{l}\text { Reports and } \\
\text { business re- } \\
\text { ports required } \\
\quad \text { by law }\end{array}$ & $\begin{array}{c}\text { Opinion: Lawful } \\
\text { and responsible } \\
\text { organization }\end{array}$ & $\begin{array}{l}\text { Government public re- } \\
\text { lations; face to face and } \\
\text { paper documentation; } \\
\text { telephone communica- } \\
\text { tion; e-mail accounts }\end{array}$ & $\begin{array}{l}\text { Enterprise's/corporate's } \\
\text { portals (personalized } \\
\text { user accounts); social } \\
\text { networks }\end{array}$ \\
\hline $\begin{array}{l}\text { Local com- } \\
\text { munities }\end{array}$ & $\begin{array}{l}\text { Actions to pro- } \\
\text { tect the envi- } \\
\text { ronment, local } \\
\text { development, } \\
\text { and support so- } \\
\text { cial initiatives }\end{array}$ & $\begin{array}{l}\text { Opinion: good } \\
\text { and environ- } \\
\text { mentally friendly } \\
\quad \text { citizen }\end{array}$ & $\begin{array}{l}\text { Social advertising, activ- } \\
\text { ities in the field of CSR }\end{array}$ & $\begin{array}{l}\text { Enterprise's/corporate's } \\
\text { portals (personalized } \\
\text { user accounts); social } \\
\text { networks }\end{array}$ \\
\hline
\end{tabular}


It should be noted, however, that the most advanced and direct form of contemporary contact with stakeholders, which is a bilateral and interactive communication type, is social media. Through these media, you can get a dialogue in the form of advisory and discussion panels, opinions and suggestions for improving cooperation, etc. Generally, social media are really distinct from traditional means of communication in three significant ways: (1) social media allow for one person to share a message with a very large number of others at very low cost; (2) social media allow for low-cost, sustained interaction among members of a social network; and (3) social media allow messages in a wide variety of forms (e.g., text, audio, animation, and video) to be traded easily among members of a network (Maxwell, Carboni, 2014). In the contemporary world social media strategies and IT technologies among organizations and their stakeholder groups within and outside of different networks are fundamental tools in organization-stakeholder relations. What is more, in the relationship management practice, social media are used as tools to reach stakeholders that might have been previously out of range (Waters, 2010).

In conclusion, it should be emphasized that a systematically conducted and planned dialogue with stakeholders can bring many benefits to the enterprise, from risk minimization, to innovative product, process, organizational or marketing solutions to acquiring a lot of information and knowledge from various groups, e.g. meeting needs and expectations. stakeholders (employees, customers, suppliers, etc.), increased loyalty of clients, employees, business partners, strengthening employee motivation and commitment, support for innovation and knowledge transfer, building a strong brand and positive company reputation (Szwajca, 2015).

\section{Role of knowledge management and knowledge sharing in innovative enterprises - the organizational and technical framework}

Knowledge management, with particular emphasis on knowledge sharing, can be directly related to the processes of enterprise communication - both with internal stakeholders (employees) and external entities (including clients and cooperating entities). This is due to the fact that communication concerns both the implementation of basic processes (resulting from the need to manufacture goods, provide services, trade in goods, project management, etc.), and maintain good relations with the wider environment (Bragantini, Licciardi, 2017; Blombäck, Brunninge, 2016). In order to create value for internal stakeholders, it is important not only to obtain useful information resources from employees and external entities, as well as to skilfully process and share these resources. Only in this way can there be a positive and strong synergy effect (Figure 1) related to the exchange and transmission of data, information and knowledge (Zaskórski, 2012; Rajhans, 2018). 
At this point, however, it should be noted that not all information resources are able to increase the value of the company and its cooperating entities. There is a category of unusable resources (e.g. data and false or incomplete information). One of the control mechanisms is the sharing of information resources and their comparison in various sources. Nevertheless, it must be remembered that uncontrolled and cursory acquisition of information resources from the environment and sharing them may intensify the negative (unfavourable) effect of knowledge synergy.

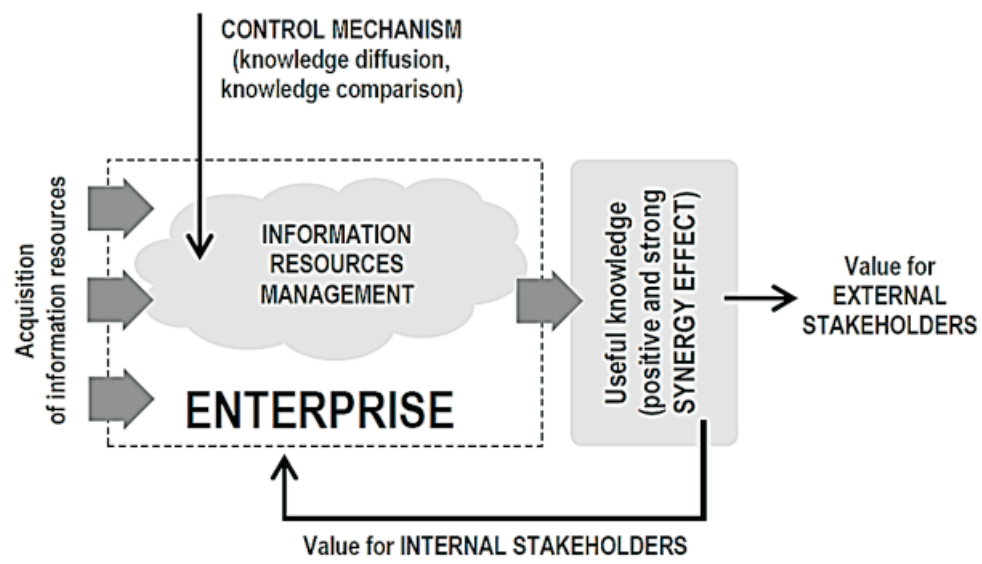

Fig. 1. Positive and negative synergy effect in the context of knowledge acquisition and sharing Source: Own elaboration based on: (Zaskórski et al., 2015)

Knowledge management, thanks to the processes of sharing information resources (the so-called diffusion of information resources), can be a source of a number of benefits for the company considered at the following basic levels (Table 4):

- business benefits - related primarily to shaping financial results, identifying and using opportunities in the environment, ensuring liquidity and generating the market value of the company, as well as supporting innovation (research and development) processes in both the long and short term (Sher, Yang, 2005);

- resource-related benefits - related to business benefits, but directly related to access to limited material resources, e.g. as a result of applying the global sourcing strategy (Chen et al., 2017; von Delft et al., 2018) or using the sharing economy potential (Geissinger et al., 2019; Leung, et al., 2019, Netter, et al., 2019; Ritter, Schanz, 2019);

- employee benefits (human resources) - mainly related to the improvement of employee competencies at various levels of management, e.g. as a result of trainings (Dostie, 2018); it is also important to draw attention to creating trust between employees in order to obtain from them the so-called quiet knowledge (Wah et al., 2018; Giest, 2019); 
- organizational/structural - related mainly to shaping access to specific information resources for individual classes of employees (so-called information asymmetry) (Zaskórski, 2012); it is also important to increase the efficiency and effectiveness of communication processes, as well as expanding the resource/information potential of auxiliary processes for the business (basic) enterprise (Bitkowska, 2013);

- technological benefits - related to access to new and modern IT technologies and their application in management processes;

- relational/network benefits - related to the entry of enterprises into permanent or periodic cooperation networks of innovative entities, aimed at creation, know-how, cooperation in the implementation of projects, etc. (Anokhin et al., 2019; Desmarchelier, Zhang, 2018);

- social/environmental benefits - focused mainly on creating social, ecological and cultural benefits, etc. for individuals located in the market environment of enterprises (e.g. clients or cooperators) or in a further environment (e.g. local communities); Social benefits are also determined by the external efficiency of enterprises' operations, i.e. the degree of adoption of the results of their business activities by external entities/stakeholders (Zaskórski et al., 2015).

Knowledge management, and in particular knowledge sharing (diffusion of knowledge), constitute a kind of "foundation" for processes related to shaping long-term enterprise development by supporting innovative activities. In principle, it can be assumed that each of the benefits listed in Table 4 "consists" of the development of innovative activity. This is mainly due to the fact that:

- innovation processes are basically based on information resources, and innovations themselves are often identified with these resources, e.g. in the context of creating know-how (production technologies, production secrets, etc.);

- innovative processes cannot be implemented without proper involvement and structured development of the human factor (intellectual capital), as well as constructive "control" of relations (both within the enterprise and with external entities) (Moczydłowska et al., 2017);

- ICT technologies (e.g. corporate portals, social media, Cloud Computing, Internet of Things, Integrated Management Information Systems, Business Intelligence, data exploration, etc.) improve the exchange of information resources and are a kind of "leverage" of creating new, useful knowledge through process support analytical, as well as allow reaching as many participants of innovative processes as possible and exchange information resources between them (Hoffman, Novak, 2018; Gyusunet al., 2017; Mącik, 2018; Attaran, Woods, 2018; Habjan, Pucihar, 2017); 
- innovative activity becomes consistent with the expectations, requirements, capabilities and needs of both the enterprise-innovator and various classes of stakeholders, and even larger communities (e.g. local communities, etc.); it is also important that the mentioned "coherence" may refer to various aspects of the innovative processes, e.g. ecological, aesthetic/artistic, legal, ecological, technical-technological, financial, etc.;

- currently, innovative processes are implemented more and more often on the basis of the so-called open innovations, going beyond the "borders" of one entity, drawing from the potential of external entities, creating, for example, clusters and cooperation networks (e.g. technological and creative clusters) (Sopińska, Dziurski, 2018);

- innovative activity of contemporary enterprises should be implemented in accordance with "balanced", holistic (socio-environmental) development, and not only in terms of "profitability" (Boons et al., 2013).

Table 4. Sample and basic benefits for enterprises stemming from knowledge management

\begin{tabular}{|c|c|}
\hline $\begin{array}{c}\text { The category } \\
\text { of benefits }\end{array}$ & Examples \\
\hline $\begin{array}{c}\text { Business (core pro- } \\
\text { cesses and innova- } \\
\text { tions and market) }\end{array}$ & $\begin{array}{c}\text { increasing the efficiency and effectiveness of innovative processes, } \\
\text { ensuring stable income and financial liquidity of the enterprise, } \\
\text { detailed recognition of the specificity of the environment (opportunities and } \\
\text { threats), }\end{array}$ \\
\hline $\begin{array}{c}\text { Resources (mate- } \\
\text { rial/technical) }\end{array}$ & $\begin{array}{c}\text { receiving access to resources that both clients and business partners have, such } \\
\text { as rare materials and raw materials, } \\
\text { may increase the quality of the company's operations and the value provided } \\
\text { to the client, }\end{array}$ \\
\hline $\begin{array}{c}\text { Employee (human } \\
\text { resources) }\end{array}$ & $\begin{array}{c}\text { recognizing the training needs of employees and raising their competences, } \\
\text { increasing employee involvement in enterprise development, } \\
\text { creating trust between employees and acquiring quiet knowledge from them, }\end{array}$ \\
\hline $\begin{array}{c}\text { Organizational/ } \\
\text { structural }\end{array}$ & $\begin{array}{c}\text { limiting data "leakage" and access to information resources of unauthorized } \\
\text { entities (e.g. competitors or saboteurs), }\end{array}$ \\
increasing the flexibility of the company in its operations,
\end{tabular}

Source: Own elaboration based on: (Mohajan, 2019; Stenius et al., 2017; Igielski, 2017; Collins, Kehoe, 2017; Bessen, Nuvolari, 2019; Lin et al., 2019; McGowan et al., 2018) 


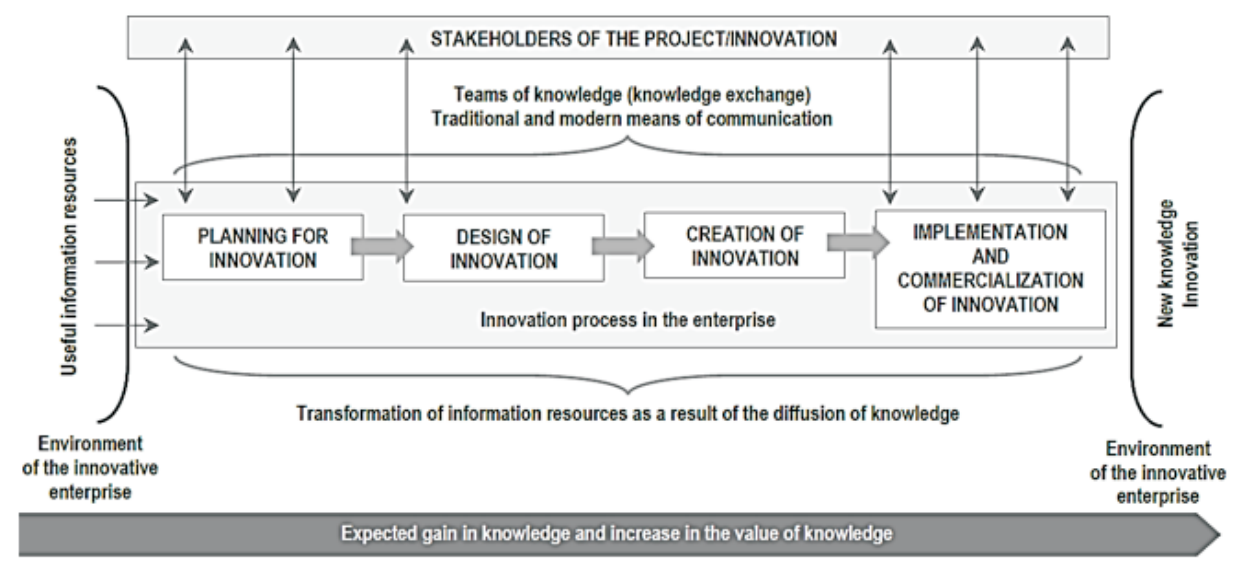

Fig. 2. Knowledge management (knowledge sharing) in the innovative activity of the enterprise Source: Own elaboration based on: (Hąbek, 2011; Wojnicka-Sycz, 2013; Janasz, Janasz, 2018)

Therefore, it can be assumed that in innovative activities of enterprises - through knowledge management - it is crucial to communicate with various groups of stakeholders using both traditional and modern forms of communication (Figure 2). It is also worth emphasizing that the necessary condition for the success of innovative processes in modern enterprises is not the use of the latest forms of communication. Traditional forms, which are also effective and effective from the business point of view, can often be sufficient.

\section{Conclusions}

Building stakeholder trust is a long-lasting process that requires establishing and then successively deepening the company's contacts with interest groups. The process is complex but the most important elements are: communication, consultation, partnership and dialogue. The most advanced form of contact is a dialogue with stakeholders which is a bilateral, intense communication in a traditional or modern form. A systematic and well-conducted dialogue gives the opportunity to use various influences of factors to better understand mutual needs and expectations, opinions or suggestions regarding various issues, i.e. to acquire and transfer knowledge between participants in the process. Moreover, each enterprise competing with another (in a context of innovative processes) should create competition networks through effective communication complexity in order to transfer knowledge, to cooperate and build trust and value in the sector. Every market power (socio-cultural, technological, economic or political) can create the right conditions for shaping a network of communication links or sharing stakeholders and knowledge in innovative processes (Figure 3). 


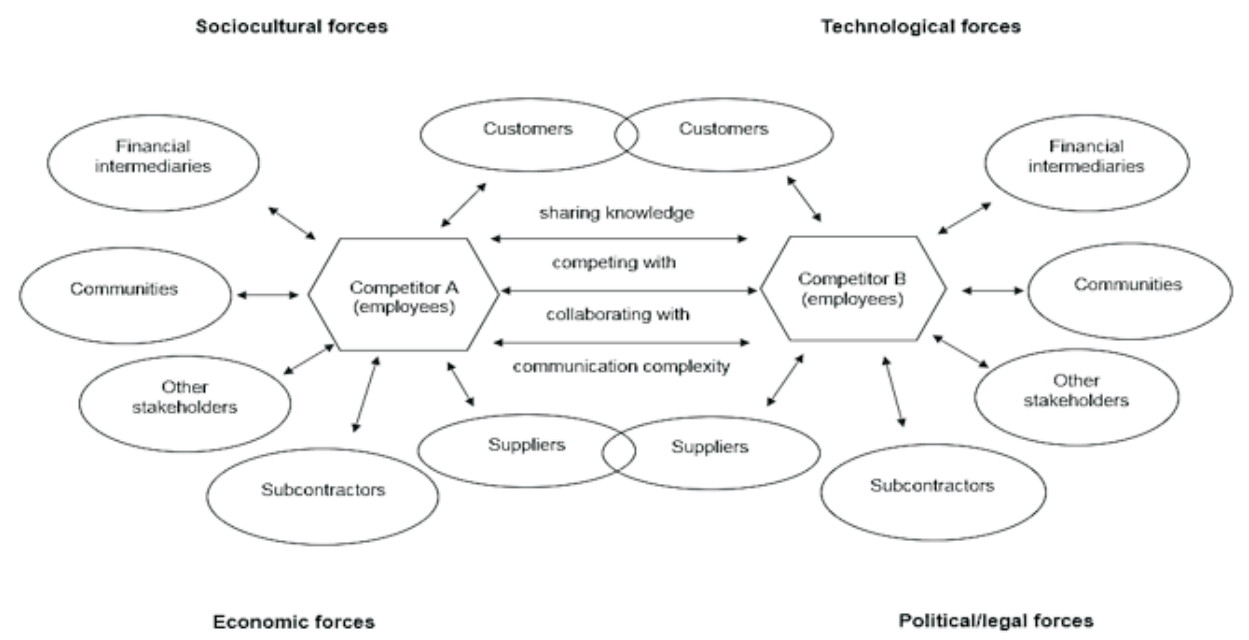

Fig. 3. Communication and competing stakeholder networks based on sharing knowledge in innovative processes

Source: Own elaboration based on: (Freeman et al., 2010)

In the literature and in the practise there is a need to develop better business models for managing stakeholder relationships and conducting innovative processes. The most important fact is that varied organizations serve a broad range of stakeholder inside and outside the unit. That is why, more attention should be paid to the creation of trust among parties and the minimization of risk in cooperation between them in innovative processes - the proposal of further research. What is more, most models of the stakeholder perspective envision competitors alongside other types of stakeholder. A very useful concept would have competing networks of stakeholders, where one competitor's network is in competition with the others but on the other side they cooperate with each other, communicate and share knowledge - in the context of innovative processes. 


\section{REFERENCES}

[1] Anokhin, S., Wincent, J., Parida, V., Chistyakova, N., Oghazi, P., 2019. Industrial clusters, flagship enterprises and regional innovation, Entrepreneurship and Regional Development, No. 31(1/2).

[2] Attaran, M., Woods, J., 2018. Cloud Computing Technology: A Viable Option for Small and Medium-Sized Businesses, Journal of Strategic Innovation and Sustainability, No. 13(2).

[3] Bessen, J., Nuvolari, A., 2019. Diffusing new technology without dissipating rents: some historical case studies of knowledge sharing, Industrial and Corporate Change, No. 28(2).

[4] BitкowsкA, A., 2013. Process management in contemporary organizations, Difin, Warsaw.

[5] Blombӓск, A., Brunninge, O., 2016. Identifying the Role of Heritage Communication: A Stakeholder-Function Framework, International Studies of Management and Organization, No. 46(4).

[6] Boons, F., Montalvo, C., Quist, J.J.N., Wagner, M., 2013. Sustainable innovation, business models and economic performance: an overview, Journal of Cleaner Production, No. 45.

[7] Bourne, L., 2009. Stakeholder relationship management. A maturity model for organizational implementation, Gower, Farnham.

[8] Bragantini, D., Licciardi, M., 2017. Stakeholders communication approach: A new era, Project Management Development - Practice and Perspectives, vol. VI, issue VII.

[9] Chen, X., Lu, Y., Zhu, L., 2017. Product cycle, contractibility, and global sourcing, Journal of Development Economics, No. 127.

[10] Collins, Ch., Kehoe, R., 2017. Examining Strategic Fit and Misfit in the Management of Knowledge Workers, ILR Review, No. 70(2).

[11] Desmarchelier, B., Zhang, L., 2018. Innovation networks and cluster dynamics, Annals of Regional Science, No. 61(3).

[12] Dostie, B., 2018. The Impact of Training on Innovation, ILR Review, No. 71(1).

[13] Fortunato, J.A., Gigliotti, R.A., Ruben, B.D., 2017. Racial Incidents at the University of Missouri: The Value of Leadership Communication and Stakeholder Relationships, International Journal of Business Communication, No. 54(2).

[14] Freeman, R.E., 2004. A stakeholder theory of the modern corporation, [in:] T.L. Beaucham, N.E. Bowie (Eds.), Ethical theory and business, Pearson/Prentice Hall, New Jersey.

[15] Freeman, R.E., Harrison, J.S., Wicks, A.C., Parmar, B.L., De Colle, S., 2010. Stakeholder Theory. The state of the art, Cambridge University Press, Cambridge.

[16] Friedman, A.M., Miles, S., 2009. Stakeholders. Theory and practice, Oxford University Press, Oxford.

[17] Geissinger, A., Laurell, Ch., Öberg, Сh., Sandström, Сh., 2019. How sustainable is the sharing economy? On the sustainability connotations of sharing economy platforms, Journal of Cleaner Production, No. 206.

[18] Giest, S., 2019. Trust Dynamics in Innovation Networks: The Chicago Life Science Cluster, Administration and Society, No. 51(2).

[19] Gyusun, H., Jeongcheol, L., Jinwoo, P., TaI-Woo, CH., 2017. Developing performance measurement system for Internet of Things and smart factory environment, International Journal of Production Research, No. 55(9).

[20] HĄBEK, P., 2011. The innovation process and new tools to improve the quality, Problemy Jakości, No. 2.

[21] Habjan, K.B., Pucihar, A., 2017. Cloud Computing Adoption Business Model Factors: Does Enterprise Size Matter?, Engineering Economics, No. 28(3). 
[22] Hoffman, D., Novak, T.P., 2018. Consumer and Object Experience in the Internet of Things: An Assemblage Theory Approach, Journal of Consumer Research, No. 44(6).

[23] IgIelski, M., 2017. Assumptions to the model of managing knowledge workers in modern organizations, Management, No. 21(1).

[24] Janasz, W., Janasz, K., 2018. Categories of Knowledge in Innovative Organisation Processes, Studia i Prace WNEiZ US, No. 52.

[25] Leung, X.Y., Xue, L., Wen, H., 2019. Framing the sharing economy: Toward a sustainable ecosystem, Tourism Management, No. 71.

[26] Lin, Y., Hongyi, M., Zongjun, W., 2019. How paradoxical leadership affects ambidextrous innovation: The role of knowledge sharing, Social Behavior and Personality: An International Journal, No. 47(4).

[27] MącıK, R., 2018. Perception of the Internet of Things Technology and Devices by Young Consumers, Handel Wewnętrzny, No. 5.

[28] Maxwell, S.P., Carboni, J.L., 2014. Stakeholder communication in service implementation networks: expanding relationship management theory to the nonprofit sector through organizational network analysis, International Journal of Nonprofit and Voluntary Sector Marketing, No. 9.

[29] McGowan, C.G., Reid, K.L.P., Styger, L.E.J., 2018. The Knowledge Enhancement Process of Knowledge Workers, Journal of Organizational Psychology, No. 18(1).

[30] MoczydŁowska, J.M., Korombel, A., Bitкowska, A., 2017. Relacje jako kapitał organizacji [Relationships as a capital of the organization], Difin, Warsaw.

[31] Mohajan, H.K., 2019. Knowledge Sharing among Employees in Organizations, Journal of Economic Development, Environment and People, No. 8(1).

[32] Netter, S., Pedersen, E.R.G., Lüdeke-Freund, F., 2019. Sharing economy revisited: Towards a new framework for understanding sharing models, Journal of Cleaner Production, No. 221.

[33] Rajhans, K., 2018. Effective Communication Management: A Key to Stakeholder Relationship Management in Project-Based Organizations, IUP Journal of Soft Skills, No. 12(4).

[34] Ritter, M., Schanz, H., 2019. The sharing economy: A comprehensive business model framework, Journal of Cleaner Production, No. 213.

[35] SACHS, S., RÜHLI, E., 2011. Stakeholders matter. A new paradigm for strategy in society, Cambridge University Press, Cambridge.

[36] SChreiber, E.S., 2001. Why do many otherwise smart CEO's mismanage the reputation asset of their company?, Journal of Communication Management, No. 6(3).

[37] Schultz, M., Nielssen, K.U., Boege, S., 2001. Nominations for the most visible companies for the Danish RQ, Corporate Reputation Review, No. 4(4).

[38] Sher, P., YANG, PH., 2005. The effects of innovative capabilities and R and D clustering on firm performance: the evidence of Taiwan's semiconductor industry, Technovation, No. 25(1).

[39] Sopińska, A., Dziurski, P., 2018. Open innovation. The prospect of collaboration and knowledge management, Warsaw School of Economics, Warsaw.

[40] Stenius, M., Haukkala, A., Hankonen, N., Ravaja, N., 2017. What Motivates Experts to Share? A Prospective Test of the Model of Knowledge-Sharing Motivation, Human Resource Management, No. 56(6).

[41] SztompкA, P., 2007. Zaufanie. Fundament społeczeństwa [Trust. The Foundation of Society], Znak, Cracow.

[42] SzwajCA, D., 2015. The importance of dialogue with stakeholders in building the company's reputation as a smart organization, Scientific Notebooks of the Silesian University of Technology, No. 86. 
[43] SzwajCA, D., 2016. Business reputation management. Construction and reconstruction of stakeholders' trust, CeDeWu, Warsaw.

[44] von Delft, S., Kortmann, S., Gelhard, C., Pisani, N., 2018. Leveraging global sources of knowledge for business model innovation, Long Range Planning (in press, corrected proof, available online 3 September 2018).

[45] Wah, N.C., Zawawi, D., Yusof, R.N.R., Sambasivan, M., 2018. The mediating effect of tacit knowledge sharing in predicting innovative behaviour from trust, International Journal of Business and Society, No. 19(3).

[46] Waters, R.D., 2010. The use of Social Media by Nonprofit Organizations: An Examination from the Diffusion of Innovations Perspective, IGI Global, Hershey, PA.

[47] Wereda, W., 2018. Model of Building Stakeholder Engagement in the Functioning of the Organization - Trust and Risk, Annales Universitatis Mariae Curie-Skłodowska, sectio H (Oeconomia), No. LII(6).

[48] Wereda, W., Paliszkiewicz, J., Lopes, I.T., Woźniak, J., Szwarc, K., 2016. Intelligent Organization (IO) towards contemporary trends in the process of management - selected aspects, Military University of Technology, Warsaw.

[49] Wóıсік, J., 2011. Ideas of the Web 2.0 and prosumers as manifestations of the mythologization of the modern world, [in:] A. Zaorska. (Ed.), Chaos or creative destruction? Towards new models in the economy and politics, Warsaw School of Economics, Warsaw.

[50] Wojnicka-Sycz, E., 2013. ICT Tools Supporting Innovation Process, Management and Finance, No. 11(4).

[51] WoźNiak, J., Wereda, W., 2018. Premises of using information and communication technologies (ICTs) in communication with stakeholders: risk management perspective, Hyperion International Journal of Econophysics and New Economy, No. 11(2).

[52] ZAsкóRsкi, P., 2012. Information asymmetry in process management, Military University of Technology, Warsaw.

[53] Zaskórski, P., Woźniak, J., Szwarc, K., Tomaszewski, Ł., 2015. Project management in a holistic approach, Military University of Technology, Warsaw. 
